\title{
Some Observations on Isoetes Drummondii, A.Br.
}

\author{
BY
}

\author{
T. G. B. OSBORN, D.Sc., \\ Professor of Botany in the University of Adelaide. \\ With fifteen Figures in the Text.
}

TSOETES DRUMMONDII is a small terrestrial species that has been recorded in West Australia and Victoria. It has recently been found in several localities in South Australia, always growing in soil that is wet in the rainy season, though not submerged, and baked dry in summer.

The presence near Adelaide of an abundance of material of an Isoetes having a subterranean stock has afforded an opportunity to make observations in the field on certain points in the biological morphology of the plant and to study its method of spore dispersal.

The material has all been collected in "South Australia, chiefly at Belair, near Adelaide, where the majority of the field observations were made. Much of the laboratory work was carried out in the Botanical Department, University of Adelaide, but it has been completed in the Cryptogamic Research Laboratory, University of Manchester, whilst holding an Honorary Research Fellowship of the University. My thanks are due to Prof. W. H. Lang, F.R.S., for facilities afforded me in his laboratory, for the generous way in which he has placed material of other species at my disposal for comparison, for his kind interest, and for helpful criticism.

\section{Field OBserivations.}

The conditions under which Isoetes Drimmondii grows have been described recently $;^{1}$ it is sufficient to recall here that in South Australia it occurs in a region of winter rainfall; 80 per cent. of the total annual precipitation (which is about 29 in. at Belair) falls in the seven months April to October inclusive. During this period the weather is cool, and the light intensity is frequently diminished by cloud or mist (though there are many intervals of bright sunlight) and the soil is often saturated. In October the temperatures become higher, and the rainfall usually diminishes

1 Osborn, T. G. B. : Trans. Roy. Soc., S. Aus., vol. xlii, pp. I-I2, I918.

[Annals of Botany, Vol. XXXVI. No. CXLI. January, 1922.] 
until in January and February it may be little more than 0.5 in. per month. The dry season extends from November to March, during which time the vegetative activity of all small herbaceous plants is at a standstill, the

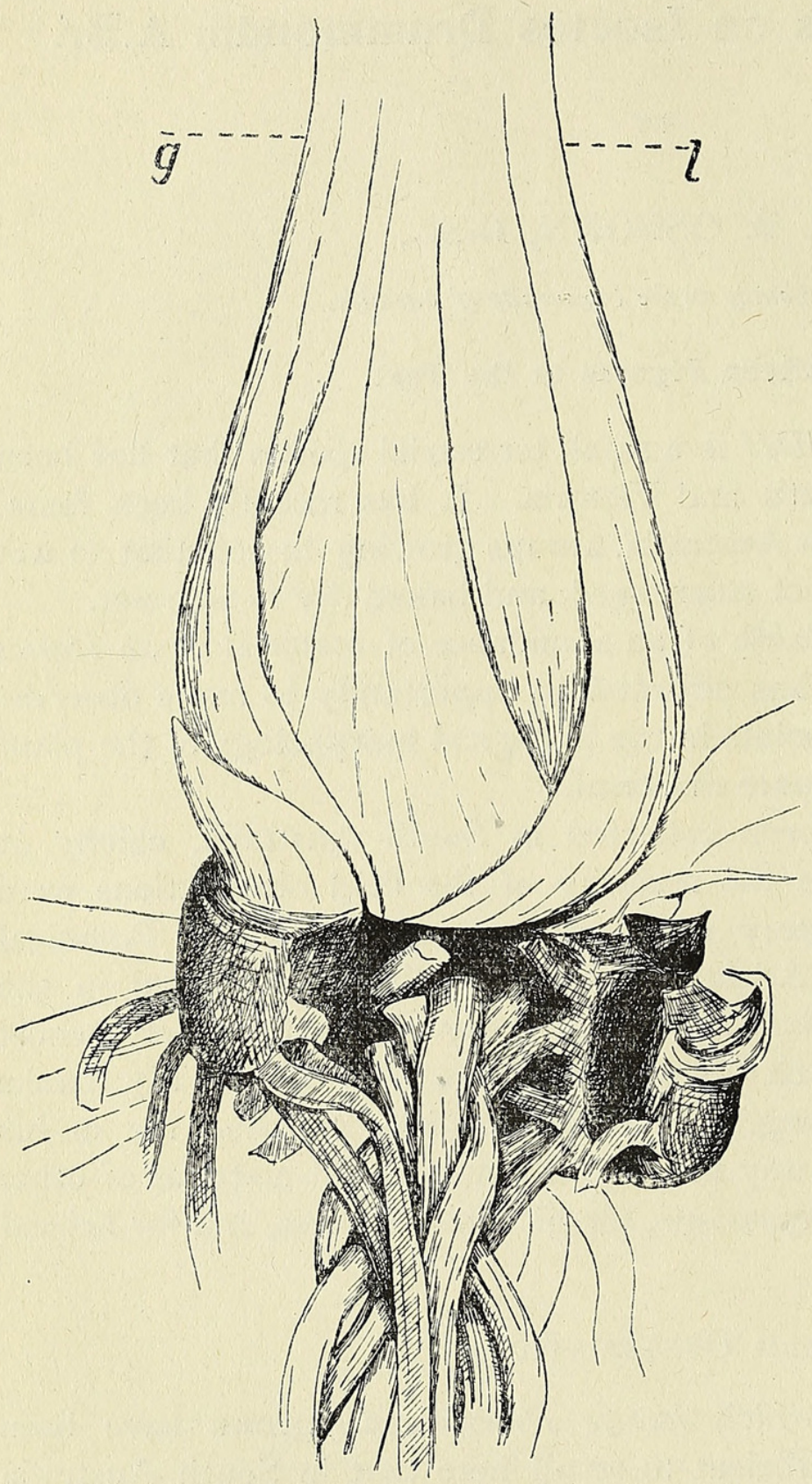

FIG. I. Subterranean portion of a plant of Isoetes Drummondii collected towards the close of the growing season. Two lobes and the groove between them are visible. Each lobe bears withered roots of the previous growing season; the functional roots issue from the groove. The lobe to the right bears the older portion as a 'cap' partially detached. temperatures high, the insolation often intense, and the soil baked hard. It is not usually until the close of May that, after several periods of heavy rainfall, the soil becomes thoroughly saturated and perennial herbs make their appearance.

The vegetative period for Isoetes Drummondii extends from the end of May or the beginning of June to November. During this time the plant forms a small rosette of from eight to twenty linear terete leaves, bright green and rather diaphanous, through which the septa of the four air-canals can be seen. Below ground the leaves collectively form a slightly bulbous structure (Fig. 1) composed of their closely imbricate, wide, membranous bases. This bulb-like base is colourless, and arises from a small trilobed stock which is buried about $2 \mathrm{~cm}$. below the surface of the soil. The stock bears a number of colourless bifurcating roots arising from the three grooves. Numerous brown withered roots are found

on the lower surface of the lobes, but it is noticeable that the upper leafbearing surface has no remains of old sporophylls upon it (Fig. 2). With the advent of the dry season the leaves become yellow and rapidly wither; 
their dry laminae may persist for some weeks, but ultimately become detached from the base somewhat below the soil level. Hence, in summer, plants can hardly be found even by careful search of small areas in which they are known to occur.

There is thus left below ground, during the dry season, the stock, bearing on its upper surface the somewhat cone-shaped mass of sporophyll

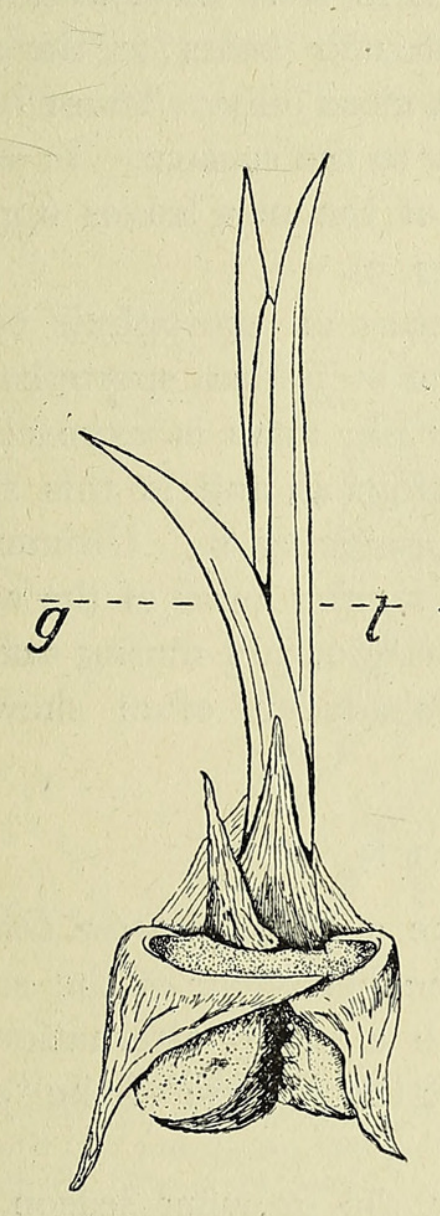

FIG. 2.

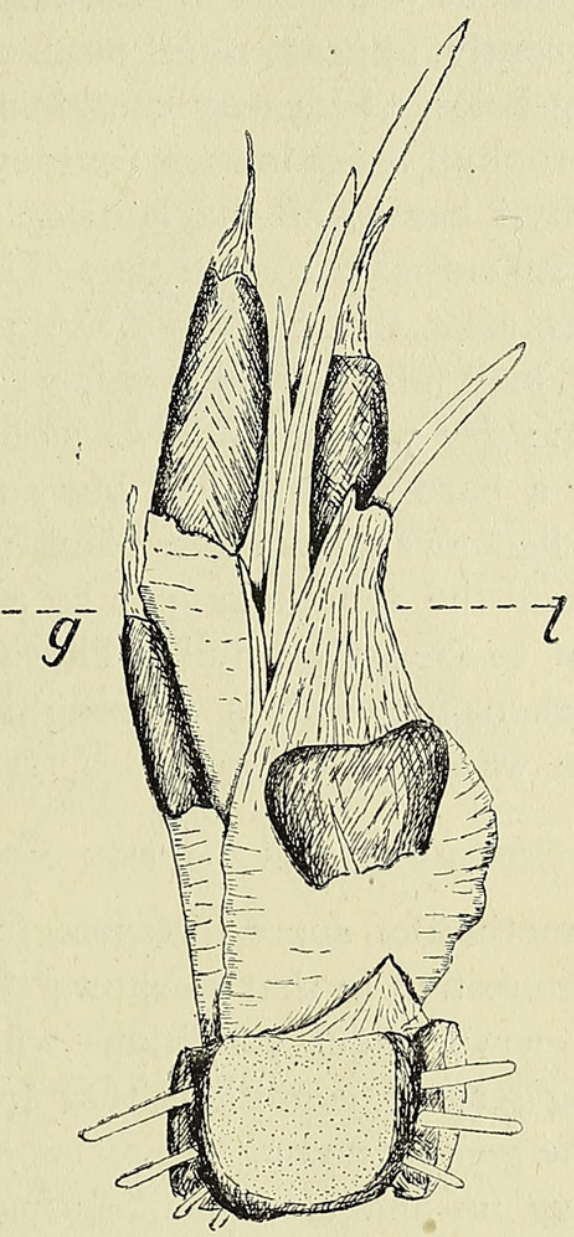

FIG. 3.

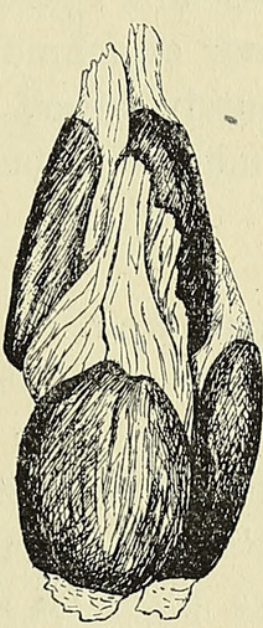

FIG. 4 .

FIG. 2. Plant collected at the opening of the vegetative season. The upper leaf-bearing surface of the stock shows a clear ring between the scales that surround the young leaves and the outer withered bases of the previous season's sterile leaves, two of which are shown reflexed. Two of the lobes are visible, the 'scar surface' stippled. The roots are cut off close to the groove. $\times 3$.

FIG. 3. Plant collected in June at the stage of elevating the old sporophylls. The mucilage tissue at the bases is much swollen by water (cf. Fig. 2, which was drawn at the same time from a similar plant from which the mucilage and sporophylls had been removed). $\times 3$.

- FIG. 4. Dry projectile-like mass of imbricate sporophyll bases, collected on surface of soil in June. Below it two dry contracted masses of mucilage can be seen. $\times 3$.

bases and the withered roots which dry up and die off completely at the beginning of the dry season. This condition persists for from four to five months. The stock has a hard brown coat formed of the sclerized outer cells over the whole of its surface, and the depressed apex is roofed over by three or four triangular imbricating scale-leaves, the cells of which are sclerized, 
About the end of May or early June the first leaves of the new vegetative season appear, while previously, below ground, a new set of roots has begun to develop upon the stock. Coincidently, or slightly before the appearance of the leaves, the bases of the previous season's sporophylls appear at the surface of the soil. These are forced upwards during such time as the soil is thoroughly sodden by the expansion of a mucilage tissue formed at their bases. In the field it is noticeable that the new leaves frequently appear from neat circular holes in the soil, rather like large worm-holes, which may contain a clear jelly. These holes are drilled by the sporophyll bases in their journcy to the surface. In other cases the old sporophyll bases and the laminae of the new leaves appear above the surface of the soil at the same time (Fig. 3).

If rain continues after the projectile-like mass of sporophyll bases reaches the surface, it may fall apart, separating the individual sporophylls ; but if a period of fine dry weather follows after the mass is exposed, it will dry up, forming a hard cone-shaped body (Fig. 4), and in this state may be blown or rolled away from the plant producing it. Ultimately the mass falls apart and the sporangia open by a tearing away of the walls from their attachment to the sporophyll. This only occurs during rain or immediately after, when the soil is thoroughly sodden, often showing a shimmer of surface water.

\section{OBSERVATIONS ON THE STOCK.}

Apart from its method of spore dispersal the study of Isoetes Drummondii has proved interesting in that it shows the behaviour of the stock of an Isoetes when grown under conditions with a sharp alternation of vegetative and resting seasons, conditions that are the reverse of the 'even growth ' implied in the generic name.

If a plant be dug up and examined during the growing season the appearance of the stock is as seen in Fig. I. The current season's leaves occupy the centre of the upper leaf-bearing surface of the stock. Externally to this are the projecting portions of the three lobes, which are composed of a series of nested scale-like caps, that usually break away upon the removal of the plant or on washing. The caps show no remains of the sporophylls that were produced on their leaf-bearing surface; all that remains of the leaves is two or three scales or the rotting bases of the few sterile leaves formed first in each season's growth.

The sides and lower surface of the stock bear numerous roots (Fig. 5). The majority are dead and brown; only those that arise from the centre of each groove are white and functional.

The structure of the lobe is of interest. It shows clearly the three types of surface distinguished by $\mathrm{Lang}^{1}{ }^{1}$ viz. the leaf-bearing surface the

1 Lang, W. H. : Mem. and Proc. Manchester Lit. and Phil. Soc, lix, No. 3, p. 9, 19 I 5. 
split surface of the groove, and the scar surface. This last in aquatic species is more or less irregular, formed by decay or removal of the distal ends of the lobes after the leaves and roots borne on that region of the stock have ceased to function.

In Isoetes Drummondii the lobe is formed of a series of nested caps, representing successive season's growth. Fach cap is bounded externally by thick-walled brown cells, bears the remains of roots, foliage-leaves, and scales of a previous season upon the lower and upper surfaces, and has also two scar surfaces. To the outer of these the more distal cap was attached,

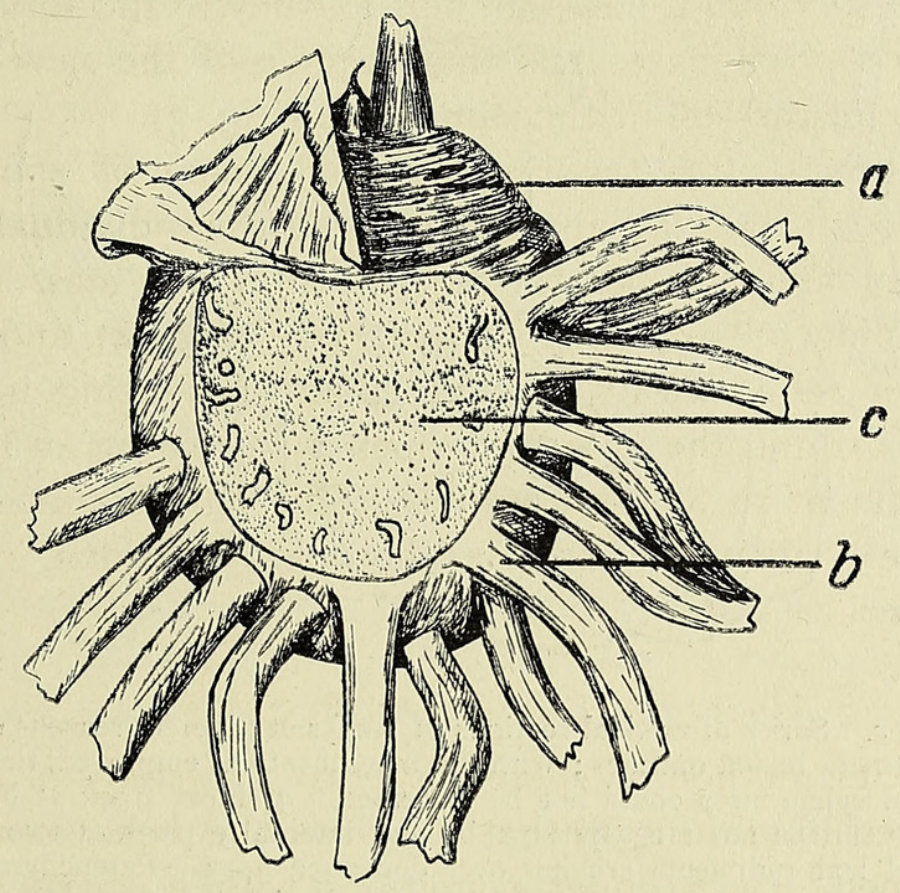

HIG. 5. A single 'cap' or desquamated stock lobe. $a$, the leaf-bearing surface, shows externally (i. e. nearer the observer) the remains of sterile leaves, some being cut away on the right, and internally two scale-leaves that protected the growing apex. The surface between was occupied by sporophylls, three scars formed by the leaf-traces of which can be seen. $b$, the root-bearing surface, with remains of one season's crop of roots. $c$, the distal 'scar' surface, to which a similar cap formed the preceding season was attached, showing withered remains of root-traces of previous season.

while the whole proximal scar surface of the cap is composed of dead parenchyma cells. In this manner the old cortex of both leaf- and rootbearing portions of the stock is sloughed annually, giving rise to the caps, but it is not removed, since the soil holds it in position. A. Braun ${ }^{1}$ noted this annual desquamation of the lobes of the stock, though he had not the knowledge of the plant in the field to connect the phenomenon with the seasonal changes that occur there.

\section{'Cap' Formation on the Lobes.}

The formation of a cap can most easily be followed in a series of median vertical sections of the stock taken at different seasons. Fig. $6, a$,

1 Braun, Alex. : Monatsbericht d. K. Akad. d. Wiss. Berlin, i 868, p. 543. 
represents a vertical section of a stock in the plane of one lobe and groove, collected during the vegetative season. It is seen that the functional starchpacked parenchyma of the stock is roughly semicircular in section. The starchy tissue is limited on the outside by a narrow band of cells (one or two wide), the walls of which are in process of becoming thickened; this band lies two or three cells below the external surface. The lobe lying on the lefthand side of the figure is no longer a part of the storage tissue of the stock. It is composed of empty parenchyma cells, which at the distal portion have

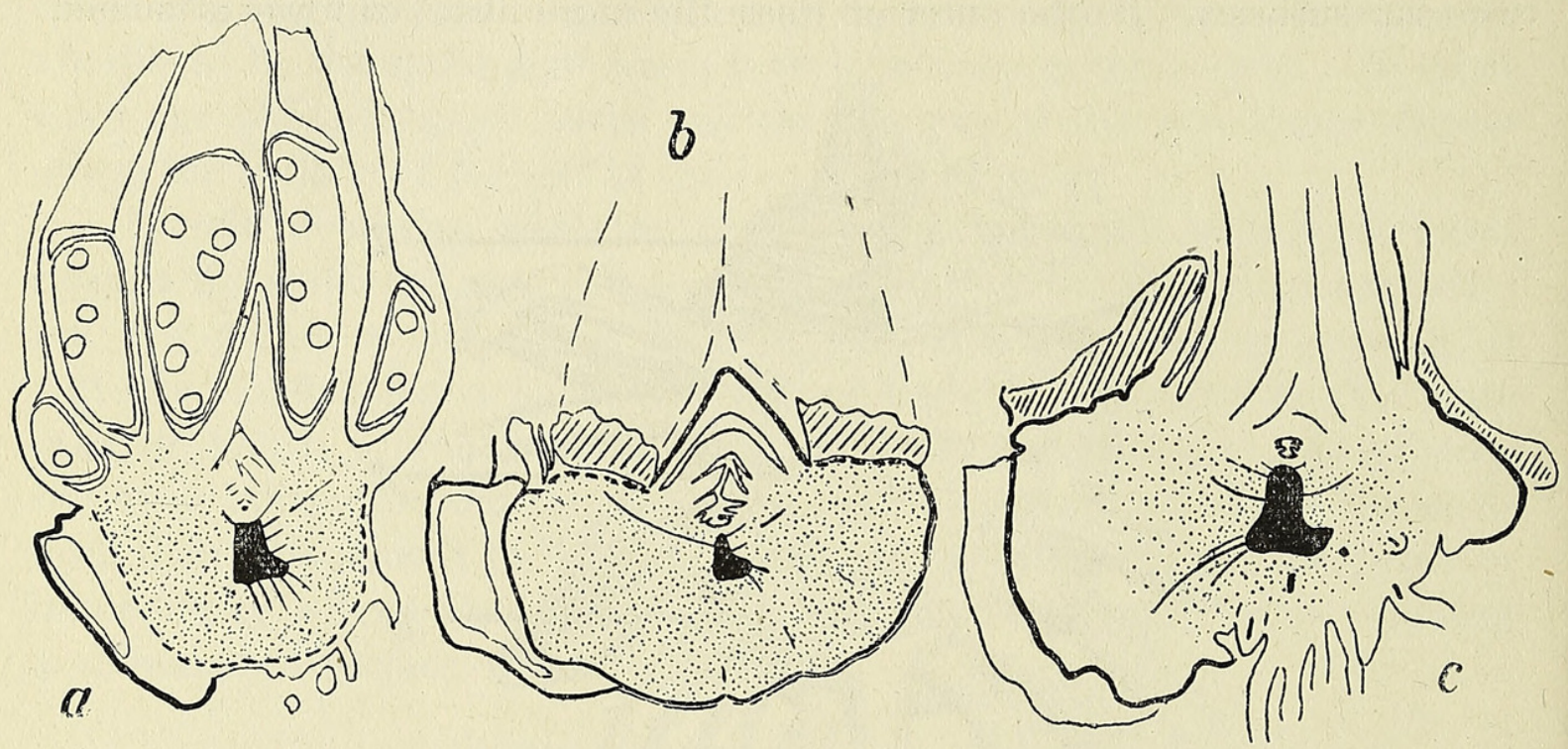

FIG. $6, a, b$, and $c$. Series of vertical sections of stocks at different seasons cut in plane of one lobe and groove. Camera lucida outlines; with the magnifications employed, the layer of prismatic tissue around the main xylem mass could not be indicated. $a$ shows stock at height of vegetative season. Leaf-bearing surface has megasporophylls and internally parts of two other leaves, then developing scales and leaf rudiments arching over depressed apex. Parenchyma of stock packed with starch; a short distance below surface a layer of cells is becoming thickened (broken line), eventually this completely cuts off roots. To left one 'cap' of lobe, its cells depleted of starch, torn apart and crushed. $\times 4 \cdot 3$. $b$ shows stock at beginning of dry season. The roots have died off, and starch-packed tissue of stock is bounded externally by sclerized cells. Sporophyll bases removed for sectioning, but outline indicated; mucilage tissue obliquely shaded; below this, position of thickened cells (not yet developed) shown by broken line. Apex and leaf rudiments protected by two scales, the outer only thickened. To left a ' cap' completely cut off from stock. $\times 6.5$. $c$ shows stock at opening of vegetative season, when sporophylls were being shed. New season's leaves expanding, position of previous season's sporophylls shown by mucilage (oblique shading). Amount of starch is greatly diminished, particularly below old sporophylls. The formation of new leaf- and rootbearing surfaces has ruptured peripheral sclerized cells; the expansion of these surfaces will crush and distort the empty parenchyma, which will eventually be cut off as caps.'Position of cap (not shown in preparation) indicated to left by light line. $\times 5 \cdot 3$.

become torn apart, while at the proximal side they have become crushed and distorted. On its free surfaces the lobe is limited by hard sclerenchymatous tissue. The whole of the parenchyma composing the lobe is moribund and in process of isolation from the stock by the layer of thick-walied cells that is forming around the storage tissue.

In Fig. 6, b, a similar section of a stock is seen at the close of the vegetative season. The peripheral sclerenchyma is continuous except below the mucilage tissue of the leaf-bearing cortex, across which it extends ultimately as far as the scales protecting the apex. The apex is roofed over in this 
specimen by two triangular imbricating scales, only the outer of which was sclerized when the specimen was collected. For sectioning it was necessary to remove the tough sporophyll bases and sporangia from the upper surface. Their attachment is shown by the mucilage tissue produced at their bases. The whole of the living parenchyma is packed with starch, and the stock at this stage is merely a perennating organ, its vegetative activity being suspended.

Fig. $6, c$, shows the condition of such a stock about six months later, when the leaves and roots of a new vegetative season have appeared, and the sporangia of a previous one are being shed. The development of new leaf- and root-bearing surfaces has caused a rupture of the continuous sclerenchyma layer. This new growth has taken place at the expense of the starch, \&c., stored in the outer region of the stock. This is now almost depleted of plastic substances at its periphery. The development of the cortex in the new leaf- and root-bearing regions forces the older parenchyma outwards, since the amount of elongation of the axis between leaf- and root-forming meristems is negligible. But, since the whole structure is subterranean and subjected to pressure by the soil on all sides, the lateral expansion at the centre causes distortion and crushing of the moribund distal portion, which, because the cells have ceased to grow and keep pace with the increasing circumference, becomes torn asunder and forms projecting lobes. These distal portions soon become cut off by sclerenchymatous tissue (cf. Fig. 6, a) and yet another cap is added to the lobe.

Thus it is seen that each annual set of caps represents the whole of the leaf- and root-bearing cortex of one growing season. ${ }^{1}$ The annual desquamation of these caps follows because of the sharp alternation of vegetative and resting seasons imposed upon a plant showing the peculiar growth mechanism of an Isoetes stock. The development each season of a starchpacked resting structure, upon which the vegetative apex is born, is analogous to the seasonal production of a corm by such a plant as Hypoxis (Iridaceae), with which Isoetes Drummondii is found associated in the field. But the analogue must not be pressed too far, for Hypoxis has the usual conical apical growing region of most plants and not an invaginated one as in the Isoetes. Consequently its stem elongates appreciably in the course of each growing season, while new roots are annually formed adventitiously around the base of the stem. Hence the old corm, composed of exhausted storage parenchyma, becomes crushed below the growing plant each year. But in Isoetes Drummondii and other species of the genus root-production is limited to certain lines on the lower surface of the stock, which enlarges each growing season to allow of their expansion. This, coupled with an

1 Lang, W. H.: loc. cit. Von Mohl, H.: Vermischte Schriften botanischen Inhalts, 1845 , pp. $122-8$. 
invaginated growing apex and the negligible growth in length of the stem each year, forces the exhausted parenchyma outwards, laterally, and so leads in Isoetes Drummondii to the development of three lobes corresponding to, and alternating with, the three lines of growth in the root-bearing region.

\section{Roots.}

The roots of Isoetes Drummondii function only for the few months of each growing season, and then die off. Every year a completely new root

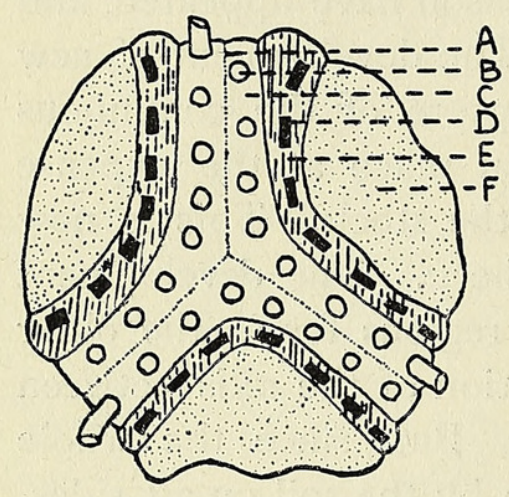

FIG. 7. Diagram to explain state of stock, as seen from below, at close of vegetative season. $A$, groove; $\mathrm{B}$, roots of current season; c, root-bearing cortex of current season ; $\mathrm{D}$, withered roots of previous season; E, root-bearing cortex of previous season; $\mathrm{F}$, scar surface.

numerous than the microsporophylls, and usually their laminae are the longest leaves formed in the year. Since the microsporophylls are the last leaves produced, and are crushed in the centre of the rosette, their sporangia often show angular compression, while their laminae may be very short.

\section{Description of the Sporophyll and Sporangium.}

The lamina of the sporophyll is linear terete, with four large air canals, over which the stomata occur; it has no sclerenchyma strands. The leaf expands below ground into the usual wide membranous wings.

The median portion of the sporophyll base from the region of the ligule to about the lower end of the sporangium becomes tough and cartilaginous towards the close of the vegetative season. This is due to an alteration in the nature of the walls of the epidermis on the abaxial surface, and, near to the ligule, of two or three layers of mesophyll cells in addition. These cells become dark brown and slightly thickened. There is thus formed a structure recalling the leaf-base or phyllopodium of Isoetes Hystrix or I. Duriaei, but it does not terminate in distal spines nor does it involve the base of the leaf to its insertion on the cortex. It forms a tough shield-shaped structure, in the concave surface of which the sporangium lies. 
The cells at the extreme base of the sporophyll of Isoetes Drummondii are not sclerized. The mesophyll cells at this region become packed with starch (Fig. 8) during the vegetative season, and towards its close their walls become mucilaginous.

In transverse sections of the leaf taken near the base of the sporangium, it is noticeable that at the initiation of the process there are two centres of

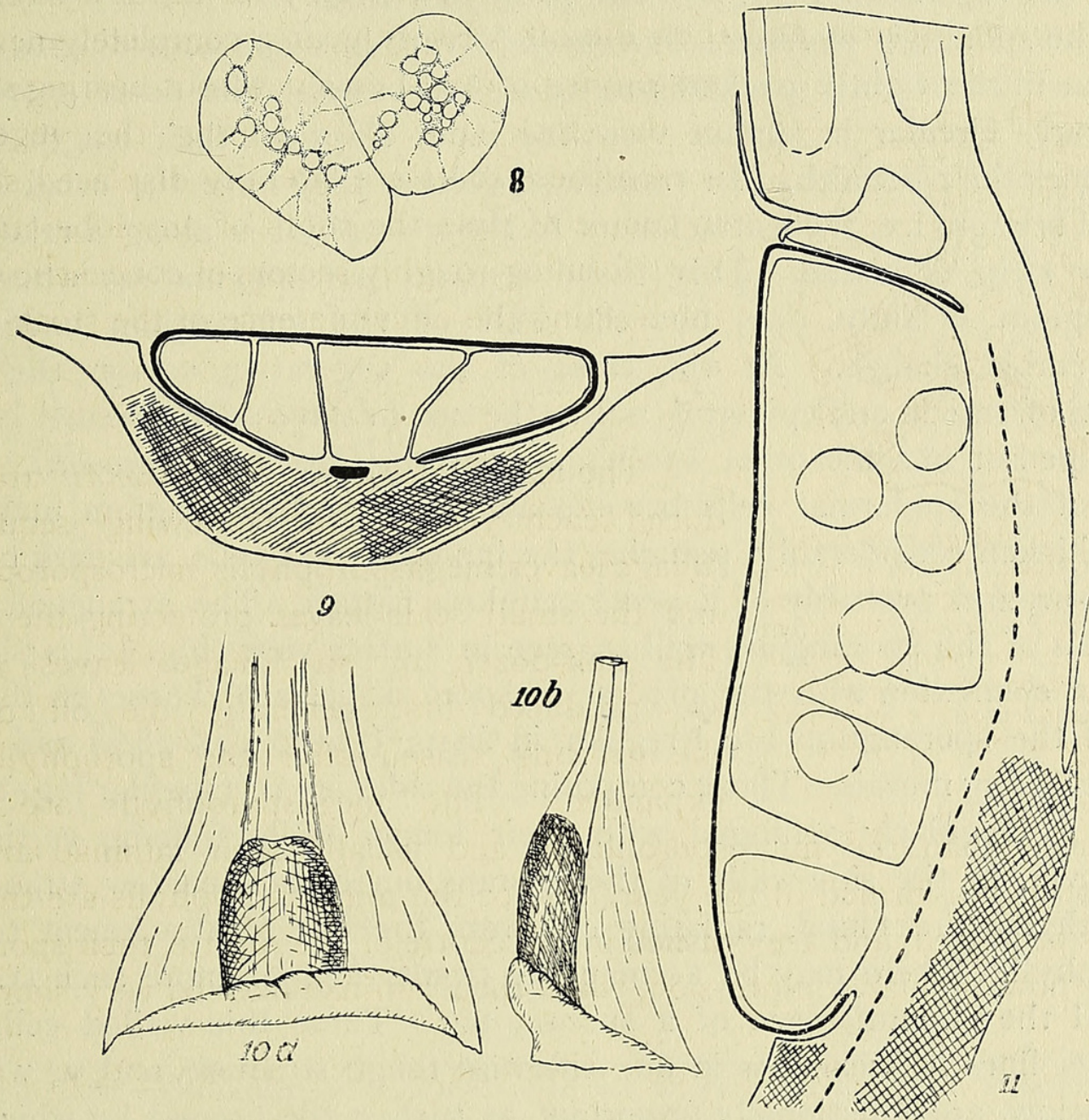

FIG. \&. Cells from mucilage tissue at base of sporophyll collected in October. The walls are already considerably thickened, but some starch remains (cf. Fig. I3). $\times 173$.

FIG. 9. Microsporophyll in transverse section. Starch-containing cells obliquely shaded, two lateral centres of mucilaginous change cross-hatched. $\times 13.5$.

FIGS. IO $a$ and Io $b$. Megasporophyll viewed abaxially (Io $a$ ) and laterally $(1 \circ b)$, showing pad of mucilage cells extending across base, also extent of tough 'shield' developed behind sporangium. $\times 2.25$.

FIG. I I. Median longitudinal section of megasporophyll collected in October. Cross-hatching shows extent of mucilage tissue. $\times 13.5$.

mucilage formation to be seen (Fig. 9), placed laterally to the leaf-trace. Later these coalesce and a continuous band of mucilage tissue results. Owing to this development there is an increase in thickness at the base of the leaf (Fig. 10), resulting in the formation of a pad or hump of mucilage cells running as a band transversely across the base of the sporophyll, tapering at either end and extending upwards behind the sporangium for 
a short distance. The bulk of the mucilage tissue is abaxial to the leaftrace, though in some cases a little is developed on the adaxial side below the level of the sporangium (Fig. I I). Mucilage also occurs in two or three of the outer cell-layers of the leaf-bearing cortex, but does not extend to any great depth in the stock. Below this sclerenchyma is developed. The process of mucilaginous thickening of the walls appears to go on until drought brings the vegetative activity of the plant to a close.

The sporangia of Isoetes Drummondii vary in shape according to their position in the tightly packed rosette of leaf-bases. The outer sporangia are nearly circular in surface view, the inner elliptical, their length being 2-4 times their breadth. In transverse section they have the usual boatshaped section, i. e. their attachment to the sporophyll is along a relatively narrow strip of tissue. This tissue remains parenchymatous when the sporangium is fully ripe, but the wall of the sporangium undergoes considerable change. At the close of the vegetative season the wall consists of cuticle and epidermis only; the two or three subepidermal layers, which persist in some other species, are lost in Isoetes Drummondii. The walls of the epidermal cells become altered as the sporangium matures: they thicken considerably, reducing the lumina of the cells, are dark brown in colour, and probably of a pecto-cellulose nature. The arrangement of the cells of the sporangium wall as seen in surface view (Fig. 12) is significant in connexion with the process of spore dispersal. Those on the flat top of the sporangium are irregular in shape $(50-70 \times 25-28 \mu)$ and form a close-fitting mosaic. Those composing the sides are rectangular $(60-100 \times$ IC $-20 \mu$ ), regularly arranged with their longer walls running vertically. Moreover, in the side-walls of the sporangium certain narrow strands of parenchyma are found, radiating out from the line of attachment to the sporophyll. There may be as many as twenty-four or more such strands around the circumference of a sporangium. These thin-walled cells are obvious lines of weakness in an otherwise tough structure, and, as will be seen below, are functionally important as such in the process by which the spores are liberated.

A further point of importance is the relation of the sporangium wall to the sporophyll. The thickened walls of the sporangium end sharply where they are attached to the parenchyma of the sporophyll, so that the whole way around the base of the sporangium there is a junction of tissues having very different mechanical properties.

\section{Process OF SPORE Liberation.}

The sporangia and sporophyll bases are in the condition just described at the close of the vegetative season. At its close there follows a period of 
four to five months when the plants are invisible below the ground, then at the end of May or in June following the spores are shed.

The first stage in the process of spore dispersal is the separation of the sporophyll bases and sporangia from the subterranean stock and the forcing of them upwards through the soil to the surface. This is effected by the absorption of water in the walls of the mucilage tissue already described. The cell-walls of this tissue absorb water with great avidity, and as a result begin to swell (Fig. I3). Having the stock below them, and the soil around, the line of least resistance is towards the surface of the soil, so
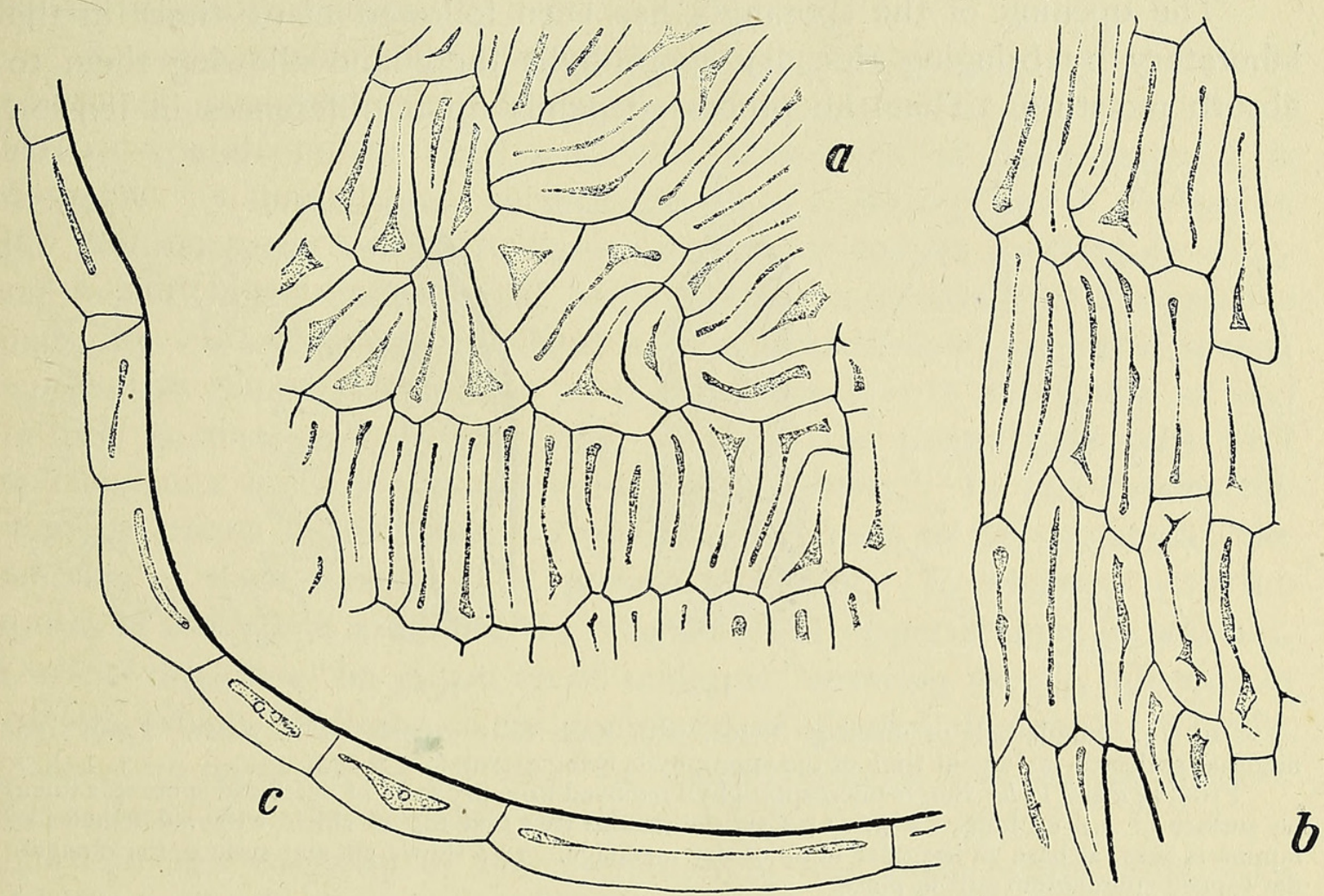

FIG. I 2, $a, b$, and $c$. $a$, ripe sporangium wall in surface view, showing irregular arrangement of cells on flat upper surface and regular shape of cells of side-walls (at bottom of figure). $b$, cells in side-wall of ripe sporangium. $c$, transverse section of ripe sporangium wall, showing cells somewhat distended with water and stout cuticle. Camera lucida outlines. $\times 93$.

that, expanding in this direction, they force the imbricate mass of sporophyll bases upwards until it reaches the surface (Fig. 3).

The second stage depends upon the continued presence of an excess of moisture. Sooner or later the mass of sporophylls becomes sodden and falls apart (Figs. $\mathrm{I}_{4} a$ and $\mathrm{I}_{4} b$ ). It is only now, when the walls of the sporangium are thoroughly saturated, that the liberation of the spores occurs. The thick-walled cells of the sporangium wall have absorbed moisture and tend to expand, but, being bounded externally by a cuticle which is less expansive than the cell-walls, the tension set up is such as to produce an eversion of the sporangium. First the wall ruptures at any point on its circumference. One or more segments of the tough wall tear away from 
their attachment to the parenchyma of the sporophyll, and from each other along the lines of weakness already noticed in the side of the wall. They rapidly roll upwards, inside out. Once the process of tearing away has begun it proceeds very quickly, and in a few seconds the whole sporangium wall has rolled back upon itself in a tight coil. Some of the spores are carried back with it, but the main mass is left in situ in the depression at the base of the sporophyll. Great numbers of megaspores and microspores are thus set free upon the break up of a sporophyll mass within a few square centimetres.

The opening of the sporangia has been followed many times in the laboratory by bringing ripe dry sporophylls there and allowing them to absorb moisture. That the process depends upon differences in tension

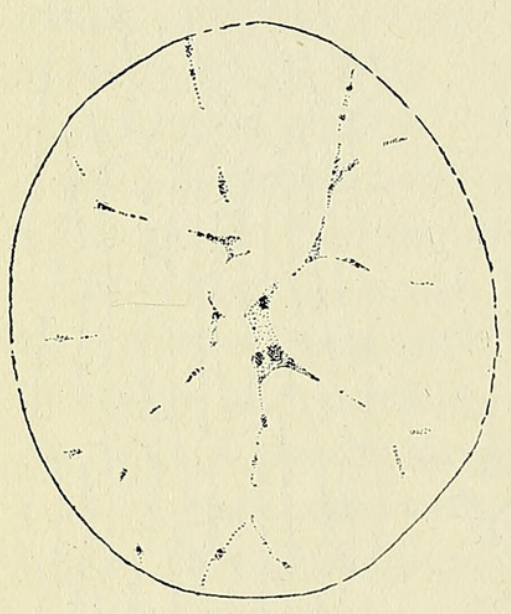

I3.

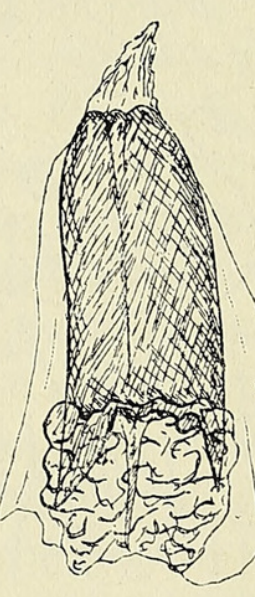

I $4 a$.

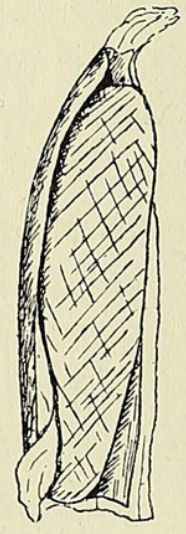

I $4 b$.

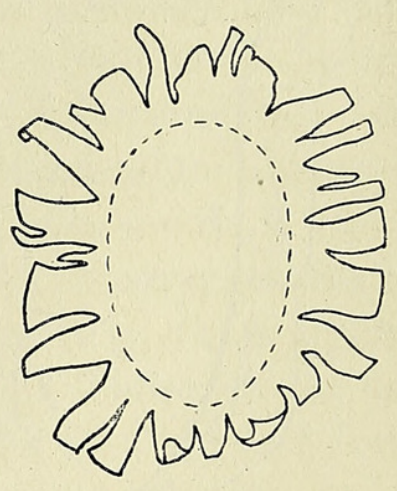

I5.

FIG. 13. Single cell of mucilage tissue, with walls fully extended with water. From fresh material collected in June at time of the sporophylls being elevated. $\times 173$.

FIGS. I $4 a$ and $14 b$. Single microsporophyll removed from dry mass of bases and sporangia found on surface of soil in June. $\times 3$. I4 a shows abaxial view; at top of shield withered remains of lamina is seen, at base an irregular lump of dry mucilage. I $b$ shows adaxial surface, the elongate flat-topped sporangium still in place.

FIG. I5. Sporangium wall in surface view, after it has torn away from sporophyll, showing fimbriated segments into which side of wall has torn.

between the inner and outer surfaces of the wall consequent upon the absorption of water can be shown by placing the freed, rolled-up sporangium. wall in different strengths of a dehydrating solution such as alcohol. A solution of $70-80$ per cent. causes the wall to unroll and float in the liquid like a membrane (Fig. I5), roughly star-shaped, with truncated points. Stronger alcohol causes the membrane to close back into its original position before tearing open. The same sporangium wall can be made to repeat the process several times by varying the proportions of alcohol and water in which it is placed.

\section{CONCLUSION.}

It is not the purpose of this paper to enter into a general discussion of the morphology of Isoetes. So far as the stock is concerned, the chief 
point of interest that an examination of Isoetes Drummondii has brought out is that, as in other species of the genus, there is a regular annual production of sets of leaves and roots upon a special cortex developed to allow of their expansion. There is a close correlation between the growth of leaf- and root-bearing surfaces which finds its expression in the development of three lobes and three clefts in the leaf-bearing cortex, to correspond with the three grooves from which the roots appear. The climatic conditions under which Isoetes Drummondii grows, resulting in a regular alternation of vegetating and resting seasons, makes the annual production of roots and leaves unusually definite.

Before a general discussion of the sporangial mechanism of the genus could be attempted much further information, derived from a study of various species in the field and with abundance of fresh material, is desirable. A further study of such species as I. Hystrix and I. Duriaei in the Mediterranean and of $I$. Butleri and other species growing in damp soil in the United States would be particularly interesting for comparative purposes. Whether any of these species would show a spore-dispersal mechanism comparable to that of $I$. Drummondii it is impossible to say. In this connexion it is interesting to recall the presence of cells with mucilaginous walls in the sporophyll of I. Hystrix. ${ }^{1}$ In this species the mucilage tissue is distributed in two strands lateral to the sporangia; the function of these strands is at present uncertain. In whatever way the spores of $I$. Hystrix are freed, the mechanism of dispersal must be efficient. Durieu ${ }^{2}$ describes ' un gazon fin et uniforme' covering certain hill-tops in Algiers, which he found to be composed of Isoetes, though at first the plants were mistaken for a grass. In South Australia it is easy to mistake the rosettes of $I$. Drummondii for those of some phanerogam.

The vast majority of the Pteridophyta free their spores under dry conditions, the familiar mechanism of the annulus depending on progressive desiccation for its action. The liberation of the spores in the subaquatic species of Isoetes appears to depend upon a process of decay. In Isoetes Drummondii there is a special mechanism for freeing the spores which depends upon saturation with water, not on dryness, for its action. ${ }^{3}$ Many of the other peculiar features of Isoetes Drummondii described above appear to be in the nature of preparations for this remarkable method of spore dispersal.

1 Hill, T. G. : Ann. Bot., xx. 267-73, I906.

${ }^{2}$ Quoted by Motelay, L., and Vendryès :'Reprint from Actes de la Soc. Linn. de Bordeaux, p. 95,1884 .

3 As it stands, the case of Isoetes Drummondii would appear to be unique among the Pteridophyta. Such xerophytic developments as the sporocarps of Marsilia and Pilularia afford only remote analogues. 


\section{SUMMARY.}

1. Isoetes Drummondii is a plant widely distributed in certain parts of South Australia, where it grows terrestrially in seasonal swamps during the period of winter rainfall. During the dry summer it aestivates, as do the other geophytes with which it is associated.

2. The stock is buried to a depth of about $2 \mathrm{~cm}$., and during the vegetative season only a small rosette of linear leaves is visible above the soil.

3. The stock is trilobed, the projecting portion of each lobe being built up of a number of segments or caps, the caps being the whole of the leaf- and root-bearing portions of the stock developed in previous growing seasons. The abscission of such caps is a result of the regular alternation of growing and resting periods (during which there is great desiccation) in the life-history of a plant having the growth mechanism of an Isoetes.

4. On the approach of the dry season the leaves dry up and become detached, leaving their tough bases and sporangia in situ upon the stock, wholly buried and invisible.

5. Early in the rainy season following, the hardened bases of the sporophylls are forced above the surface of the soil in a projectile-like mass, carrying with them the sporangia, by the expansion of certain pads of mucilage cells formed at the close of the previous vegetative season on the extreme bases of the sporophylls and from the superficial cells of the leaf-bearing cortex. About the same time the leaves of the new vegetative season begin to appear.

6. The imbricate mass of sporophyll bases breaks up upon the surface of the soil, and the spores are set free by a tearing away of the sporangium wall from its attachment to the sporophyll when sodden. This is due to a difference between the tension of the inner and outer surfaces of the sporangium wall when saturated, and results in an eversion of the wall. 


\section{$2 \mathrm{BHL}$ Biodiversity Heritage Library}

Osborn, T G B. 1922. "Some observations on Isoetes drummondii, A.Br." Annals of botany $36,41-54$.

https://doi.org/10.1093/oxfordjournals.aob.a089786.

View This Item Online: https://www.biodiversitylibrary.org/item/234428

DOI: https://doi.org/10.1093/oxfordjournals.aob.a089786

Permalink: https://www.biodiversitylibrary.org/partpdf/319026

\section{Holding Institution}

Smithsonian Libraries

\section{Sponsored by}

Biodiversity Heritage Library

\section{Copyright \& Reuse}

Copyright Status: Not in copyright. The BHL knows of no copyright restrictions on this item.

This document was created from content at the Biodiversity Heritage Library, the world's largest open access digital library for biodiversity literature and archives. Visit BHL at https://www.biodiversitylibrary.org. 